\title{
EMOCE VYVOLANÉ ZVÍŘATY I: KRÁSA A ESTETICKÉ PREFERENCE
}

\author{
Silvie Rádlová, Markéta Janovcová, Jakub Polák, Eva Landová, Daniel Frynta
}

\begin{abstract}
Abstrakt
Zviŕata vždy představovala důležitou součást života člověka, a proto v něm mohou vyvolávat nejrůznější emoce. V této práci jsme se zaměřili na pozitivní emoce, které v nás zvířata vzbuzují, a to zejména na krásu viděnou lidskýma očima. Jelikož na světě existuje velké množství druhů patřících do různých taxonomických skupin, je důležité se podívat, jak lidé zviŕata kognitivně kategorizují a jaké charakteristiky ovlivňují hodnocení krásy v každé skupině zviřat zvlášt'. Zajímalo nás, zda krásu ovlivňuje velikost a tvar těla nebo barevnost či vzor jednotlivých druhů. $\mathrm{V}$ předchozích pracích byla úspěšně využita testovací metoda předkládání stimulů $\mathrm{v}$ podobě fotografíi zvířat, které respondenti hodnotí podle vnímané krásy. Na základě této metody vzniklo mnoho prací zkoumající vztah ke zvířatům (jak pozitivní, tak negativní) a umožnilo provádět výzkumy i v jiných zemích. Mezikulturní srovnání vnímání krásy je důležitou součástí výzkumu krásy zvířat, nebot' umožňuje porovnat názory lidí na zviŕăa $\mathrm{z}$ odlišných kulturních prostředí, včetně domorodých obyvatel žijících dodnes v lovecko-sběračském uspořádání. Pokud by totiž byly znaky určující, co je na zvíratech krásné, mezikulturně shodné, dá se předpokládat, že pozitivní vnímání zvírat se vyvinulo v evoluci dřive, než lidé osídlili celý svět, a tudíž není závislé na současném prostředí. Vnímání krásy zviřat není zajímavé jen $\mathrm{z}$ hlediska evoluce, ale dává nám možnost využít tyto poznatky v cílených kampaních na pomoc ohroženým druhům zviŕăat. Tato práce je shrnutím výsledků studií zabývajících se pozitivním vnímáním zvířat na různé úrovni a $\mathrm{v}$ různých souvislostech a přináší ucelený pohled na vnímání krásy zvírat u lidí.
\end{abstract}

Klíčová slova: pozitivní emoce, krása zvířat, mezikulturní shoda

\section{EMOTIONS TRIGGERED BY ANIMALS I: BEAUTY AND AESTHETIC PREFERENCES}

\begin{abstract}
Animals have always represented an important part of life and thus they can evoke a wide range of emotions. This work has focused on the positive emotions evoked by animals in humans, specifically beauty as seen by human eyes. Since there is a multitude of species in the world that belong to various taxonomic groups, it is important to examine, how humans cognitively categorize them and what characteristics influence the perception of beauty in individual groups. The question was whether the size and shape of the animals' bodies or their colour and markings influence their beauty. Previous research has successfully employed the testing method of presenting stimuli in form of photographed animals, which were then rated by respondents according to perceived beauty. Numerous works based on this method originated, studying both positive and negative attitude towards animals, which enabled further research to be carried out in other countries. Cross-cultural comparison of the perception of beauty is an important part of the research of animal beauty, because it allows a comparison of opinions on animals of people from different cultural backgrounds, including native groups still living in hunter-gatherer hierarchy to this day. Identical features of what is seen as beautiful across cultures would imply that the positive perception of animals evolved before the humans settled the whole world and is thus independent of the current environment. The perception of animal beauty is an interesting subject not merely from an evolutionary standpoint, but also since it opens a possibility to use the findings in campaigns targeted to help endangered species. This work is a summary of results of studies focused on positive perception of animals on different levels and in different contexts, and it offers a concise overview of the perception of beauty by humans.
\end{abstract}

Keywords: positive emotions, animal beauty, cross-cultural agreement

Došlo: 3. 4. 2018

Schváleno: 20.11. 2018 


\section{Úvod}

Ekman \& Cordaro (2011) popisují základní emoce jako diskrétní fyziologické odpovědi na důležité životní situace, které nám v minulosti pomáhaly přežít. Rozlišují nejméně sedm základních emocí, jež jsou sdíleny mezi rozdílnými kulturami všude na světě, konkrétně vztek, strach, překvapení, smutek, odpor, opovržení a štěstí. Někteří autoři tvrdí, že určitá zvířata budí v člověku konkrétní emoční odpovědi snáze než jiná a že mohou též častěji představovat předmět fobií ze zvířat (Polák, Sedláčková, Nácar, Landová a Frynta, 2016). Vysvětlením může být, že tato zvířata v minulosti představovala pro naše předky bud'to skutečné nebezpečí v podobě fyzického napadení a zranění (Seligman, 1971), nebo že byla spojována s nemocí a zamořením (Matchett \& Davey, 1991). Podobně je možné si představit, že budou mít některá zvířata na člověka univerzálně pozitivní vliv. Lidé se nejen zvířat bojí či se jim snaží vyhnout, ale také je přirozeně vyhledávají (což popisuje tzv. teorie „,biofilie“, Wilson, 1984) a vytváŕí si k nim pozitivní postoj a estetické hodnocení (Thornhill, 2003).

Cílem tohoto článku je přinést souhrnný přehled o tom, které kognitivní a emoční aspekty člověka jsou ovlivněny zvířaty a které konkrétní znaky a vlastnosti těchto zvířat na člověka působí pozitivně. Zaměříme se na znaky, které působí na hodnocení estetické krásy vnímané lidskýma očima, vyvolávající pocit radosti. Ukážeme si, jaký důraz klade člověk na velikost těla, tvar, vzor, barevnost a další faktory při hodnocení krásy zvířat. Seznámíme se s metodologickými možnostmi, jak testovat pozitivní emoce vyvolené zviŕaty u lidí a jak se na tomto hodnocení shodnou lidé $\mathrm{z}$ různých kultur. Na závěr si ukážeme, že studium toho, jak na člověka působí zvířata, je samo o sobě nejen velice zajímavé, ale i důležité, nebot' lidský pohled na ostatní živočišné druhy může mít př́mý dopad jak na každodenní život člověka, tak na samotné přeživání či vymření živočišných druhů v př́rodě.

\section{Vnímání zvířat člověkem, jejich kategorizace a výběr vhodných stimulů}

Pojem „zvíře“ je velice široký. Dle databáze IUCN je dnes popsáno celkem 1889587 živočišných druhů (IUCN 2017) a tento počet se neustále zvyšuje s popisy dalších a dalších druhů. Většinu z těchto druhů tvoří bezobratlí živočichové, přičemž mezi ty nejpočetnější patří zejména hmyz (1 000 000), pavoukovci (102 248), měkkýši (85 000), korýši (47 000) a koráli (2175). Ale i pokud nasměrujeme náš pohled pouze na obratlovce, stále nám zbývá 64788 druhů, což je mnohem více, než je člověk schopen pojmout nebo si zapamatovat. Antropologové a etnobiologové na základě studií kmenových populací lovců a sběračů popisují, že počet základních pojmů pro pojmenování jednotlivých druhů zvírat (resp. konceptu každého jednoho zvířete) většinou nepřesahuje 500 jednotek (viz souhrn v Berlin, 1992). Naše mentální kapacita, jež se věnuje poznání zvířat, je tedy velmi malá ve srovnání s existující diverzitou všech obratlovců. Proto chceme-li se respondentů ptát, jak moc se jim dané zvíře líbí nebo jaké v nich vyvolává pocity, je třeba vybrat smysluplný a zároveň reprezentativní soubor druhů (Landová, Lišková \& Frynta, 2014), které jsou si př́buzné a zároveň do jisté míry sdílí podobné morfologické znaky. Zde je potřeba skloubit lidskou schopnost kategorizace s dnes standardním vědeckým taxonomickým rozdělením.

Zatímco taxonomické rozdělení se řídí především stupněm příbuznosti jednotlivých linií zvířecích druhů, lidské percepční a kategorizační procesy fungují na bázi porovnání vzhledové variability (Landová et al., 2014). Dle Berlina (1978) je základní úroveň klasifikace taková, která obsahuje maximální počet společných vlastností a zároveň se nejvíce liší mezi jednotlivými tř́dami. Tím se ovšem může lišit základní úroveň vědecké kategorizace od kategorizace běžné veřejnosti. Např́iklad člověk bude jinak vnímat velice př́ibuzné druhy, jakými jsou napřr. lev, tygr a jaguár (vědecky rod Panthera, čeled' kočkovití, řád šelmy), protože jsou na první pohled vysoce variabilní, a snáze z nich učiní základní klasifikační jednotku než například z jednotlivých netopýrů, kteří si jsou 
vzájemně velmi podobní. Podčeled Vespertilioninae (praví netopýři) obsahuje 51 různých rodů a celkem asi 439 druhů (Burgin, Colella, Kahn, \& Upham, 2018), přičemž všichni nesou jednotný český název „netopýr“ (pokud nějaký název vůbec mají). Odlišnou úroveň kategorizace jednotlivých skupin zvírat přitom mohou ovlivňovat i další faktory, než je vzhledová podobnost např. nápadnost (často dána tělesnou velikostí) nebo podobnost člověku. Příkladem posledního jmenovaného faktoru by mohli být kalmaři (což jsou bezobratlí mořští živočichové z několika různých čeledí podřádu Oegopsida), kteří nejsou nijak blíže rozlišováni a kategorizováni přes to, že některé druhy mohou dorůstat až 2,5 metru (Rodhouse, Griffiths, \& Xavier, 2014) a jednotlivé čeledi jsou přitom relativně morfologicky odlišitelné.

Pokud tedy člověk hodnotí zvíře, dívá se sice na konkrétní druh, ale ve skutečnosti u něj probíhá podvědomá kategorizace (Pothos \& Chater, 2002; Pothos \& Close, 2008). Zdá se, že samotné hodnocení je kontextově specifické - závisí na tom, do které kategorie druh spadá, a vlastnosti, které činí krásným hada (např. červená barva), nemusí nutně zároveň činit krásným ptáka (Lišková \& Frynta, 2013; Marešová, Landová \& Frynta, 2009b). Stejná vlastnost navíc může ovlivnit konkrétní hodnocení, naprríklad strachu, a na jiná hodnocení (podle krásy, podle znechucení) nemusí mít vliv (Peléšková, 2016). Také v rámci různých širších kognitivních kategorií (např̀. ptáci, plazi, savci) může mít stejná vlastnost i vliv opačný, napřr. při porovnávání krásy je zelená barva hodnocená pozitivně u ptáků z čeledi pitovití (Lišková, Landová \& Frynta, 2015a), ale vezmeme-li skupinu papoušků, zelená barva jim na kráse ubírá (Frynta, Lišková, Bültmann \& Burda, 2010). Při studiích emocí vyvolaných zvířaty a pohledu člověka na zvířata obecně je tedy potřeba velmi dobře vybrat sadu druhů, které budou respondenti hodnotit (Landová et al., 2014).

\section{Testování pozitivních emocí vyvolaných zvíraty}

Metodickou výhodou zkoumání emocí vyvolaných zvířaty je fakt, že člověk dokáže hodnotit fotografie stejně, jako kdyby hodnotil skutečná zviŕata (Landová, Marešová, Šimková, Cikánová \& Frynta, 2012), a to nejen lidé moderního světa; tento jev lze pozorovat napríklad i u afrického kmene Baka z Kamerunu, který dodnes žije tradičním způsobem lovců a sběračů (Yasuoka, 2006) a $\mathrm{v}$ podstatě nemá kontakt $\mathrm{s}$ televizí a $\mathrm{s}$ internetem. Přesto je třeba dbát na prŕísnou standardizaci stimulů (viz obr. 1), protože zejména různý světelný kontrast (Lišková et al. 2015a) nebo přítomnost modrých či zelených odlesků (Poláková, 2016; Ptáčková, Landová, Lišková, Kuběna \& Frynta, 2017) mohou ovlivnit preference samotných obrázků, nezávisle na skutečném vzhledu zobrazovaného zvířete. Vliv může mít i pozadí nebo pozice objektů na obrázku. Při důkladné kontrole těchto stimulů však představuje předkládání obrázků zvířat ideální a běžně akceptovanou metodu (Gunnthorsdottir, 2001), která se hodí zvlášt' v podmínkách, kde nelze využít pokročilejší př́stroje, jakými jsou např. oční kamera nebo měření fyziologie (pro souhrn metod testování lidských preferencí viz Landová et al. 2014, Lišková, 2013), např. právě při terénních výzkumech nativních populací v Africe či Indonésii.

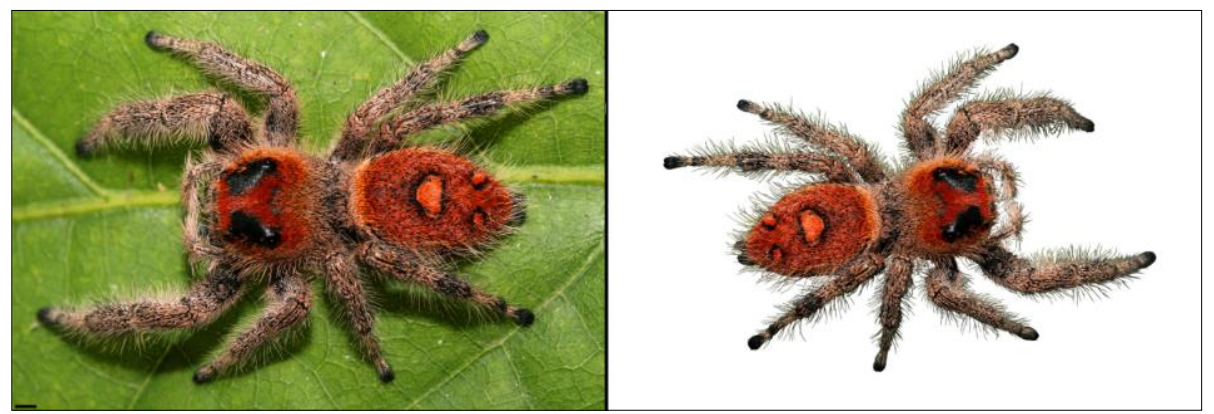

Obr. 1: Původní fotografie skákavky (Phidippus regius) a standardizovaná podoba stimulu pro testování (autor původní fotografie David Hill, @ Flickr, CC BY 2.0) 
Ve všech pracích Frynty a kol., které se zabývají lidským pohledem na zvířata, se vždy ptáme na tzv. vizuální krásu, „krásu viděnou“. Je velmi důležité uvědomit si, jakým způsobem se vymezuje tento pojem oproti pojmům souvisejícím, jako jsou atraktivita, líbivost (angl. like, „mít rád“), nebo př́ijemnost (pleasantness). Často zaměňovaným termínem je též estetická krása. Konkrétní znění úkolu, jejž zadáváme respondentům, může totiž významně ovlivnit výsledky, a je proto nutné vždy vědět, co konkrétního nám odpovědi sdělují o tom, jaký je vztah lidí k daným stimulům. Jedno mají výše zmiňované pojmy společné - popisují pozitivní působení na člověka, které vzbuzuje, nebo může vzbuzovat (i když ne výlučně), pozitivní emoci radosti. Kühn \& Gallinat (2012) provedli meta-analýzu studií, jež se zabývají hodnocením (self-report) stimulů na pozitivní škále. Do své analýzy zařadili práce, které využívaly různé pojmy, jako jsou právě krása, atraktivita, líbivost a př́ijemnost, a zjistili, že ve většině př́ípadech stimuly, jež byly tímto způsobem hodnoceny, vyvolávaly neurální aktivitu v oblasti mediální orbito-frontální kúry (mOFC) a ventrálního striata, tj. struktur, jež jsou součástí tzv. okruhu odměňování (reward circuit, viz např. Burgdorf \& Panksepp, 2006; Liu, Hairston, Schrier, \& Fan, 2011).

Některé pojmy však mohou zahrnovat i negativní působení či emoce. Pojem „estetika“ je nejčastěji spojován se slovy krása a ošklivost (Jacobsen, Buchta, Köhler \& Schröger, 2004) a rovněž pojem „atraktivni'“ může být ambivalentní. Atraktivní objekty přitahují zájem, ale tento zájem může být i negativní. Např. Woods (2000) zkoumala preference australských respondentů vůči zvířatům. V daném př́ipadě měli respondenti naprostou volnost při výběru a jejich úkolem bylo sepsat pět svých nejoblíbenějších zviŕrat, přičemž ptakopysk se zde umístil výše (preferovala ho 4,2 \% všech respondentů) než panda (není specifikováno jaká; preferována 3,2 \% respondentů).

Pro srovnání při hodnocení vizuální krásy podle tištěných fotografií se ptakopysk umístil na posledním místě, tj. jako nejméně krásný („ošklivý‘), ze všech tzv. „,bazálních savců“ a naopak panda červená byla hodnocená jako nejkrásnější zvíre ze skupiny Laurasiatheria (tj. skupina placentálních savců, Frynta et al. 2009). Panda červená se jakožto nejkrásnější umístila první i v rámci studie všech savčích čeledí (Frynta, Šimková, Lišková \& Landová, 2013) a předčila ji pouze panda velká. Oproti pandám jsou však ptakopyskové velmi bizarní zvířata, a tak není divu, že se v práci Woods (2000) objevili jako jedni z nejoblíbenějších zvířat. Sami respondenti při udávání důvodů, proč preferují právě zvířata, která zvolili, udávali mimo jiné vlastnosti jako je „unikátní“ a „zajímavý“. Samotné negativní vizuální či emocionální hodnocení zvířat proto nutně neznamená, že k danému zvířeti bude mít člověk i negativní postoj (Almeida, Vasconcelos \& Strecht-Ribeiro, 2014; Torkar, Kubiatko \& Bajd, 2012). Ve většině našich prací se pozitivní hodnocení zvířat podle vizuálně vnímané krásy často pojí s kladnými emocemi, i když to neznamená, že by současně nemohly být prožívány i jiné emoce (Landová et al., 2012; Myers, Saunders \& Birjulin, 2004).

\section{Co je na zvíratech krásné?}

\section{Analýza znaki}

Důležité je znovu si připomenout, že konkrétní znaky ovlivňující vnímání krásy se mohou lišit $\mathrm{v}$ různých taxonomických skupinách zvířat. Proto je nutné pečlivě analyzovat jednotlivé znaky na každém stimulu předkládaného druhu $\mathrm{v}$ testované sadě obrázků. Jedná se o morfologické charakteristiky (tj. rozměry těla zvířete), které se měři na konkrétním standardizovaném stimulu. Výběr rozměrů měřených na druzích zahrnutých $\mathrm{v}$ jedné testovací sadě musí být stejný, aby bylo možné určit, které znaky $\mathrm{v}$ tomto konkrétním případě nejvíce krásu ovlivňují. Také musí odpovídajícím způsobem reprezentovat tvarové charakteristiky vybrané skupiny (Obr. 2); např́ílad pokud zkoumáme skupinu hadů, nemohou být zahrnuty údaje o končetinách, ale budou zde důležité rozměry hlavy, očí a tvar těla (celková délka a jeho mohutnost). Do konečné analýzy je možné 
zahrnout i reálné rozměry zvířete, ve většině případů reprezentované délkou/výškou těla či jeho hmotností (Frynta et al., 2013; Janovcová, 2015; Poláková, 2016).

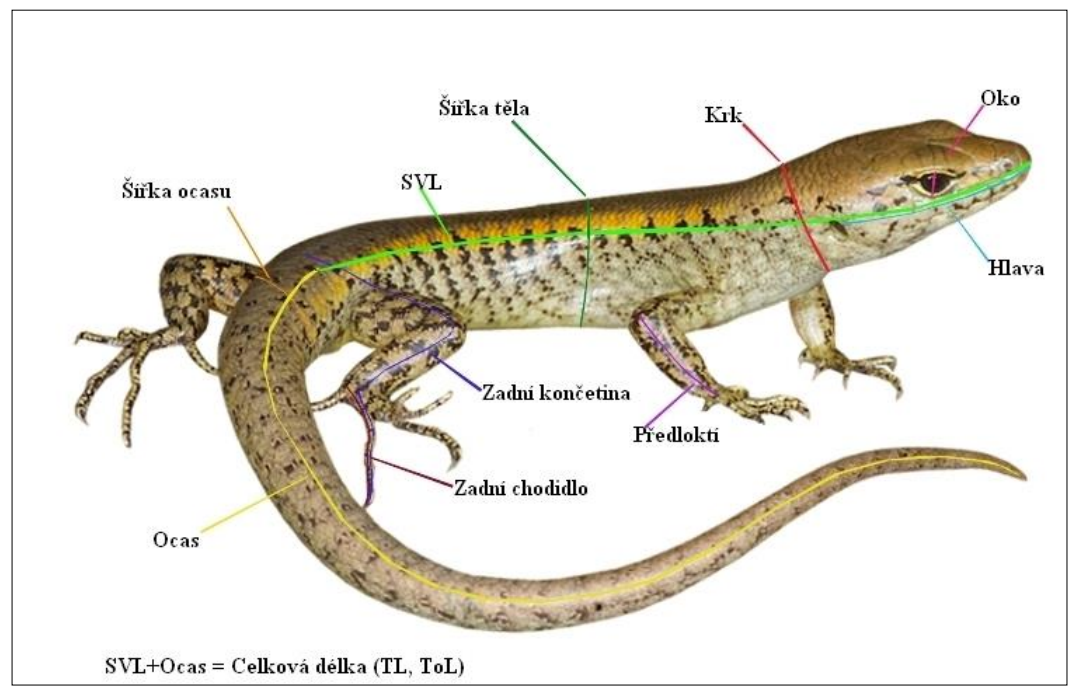

Obr. 2: Př́íklad měřených morfologických charakteristik v souboru ještěrů - zde ukázáno na scinkovi Eulamprus tigrinus (autor původní fotografie Stewart Mcdonald, @ Flikr, použito se svolením autora; grafická úprava obrázku Markéta Janovcová)

Dalšími zkoumanými znaky je prŕtomnost barev, jejich odstín, sytost, světlost a složitost vzoru zviŕrete. K analýze těchto charakteristik vyvinuli Lišková a Frynta (2013) speciální program Barvocuc (použití programu a další informace viz Lišková a Frynta 2013; Rádlová, Viktorin a Frynta, 2016 a Landová et al., 2018; Obr. 3).

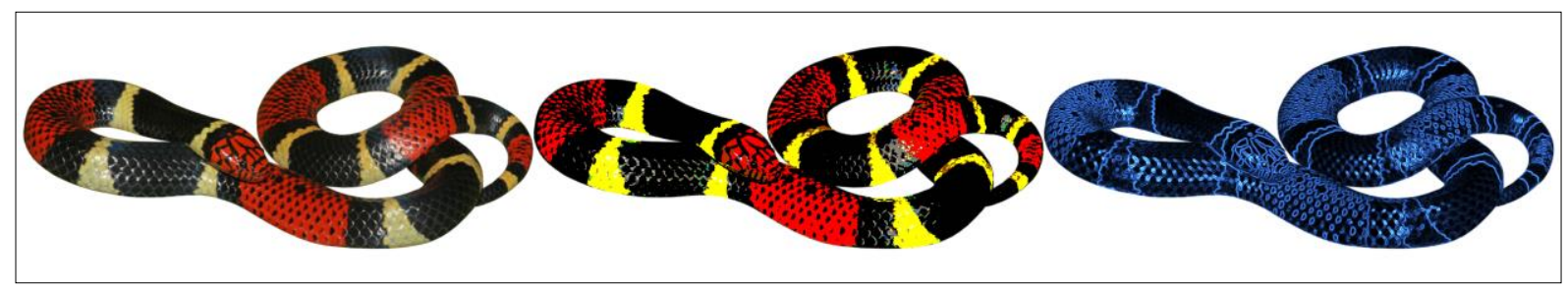

Obr. 3: Ukázka grafického výstupu ze speciálního programu Barvocuc. Vlevo původní obrázek, uprostřed barvy detekované programem, vpravo analýza složitosti vzoru zvířete; zde korálovec Micrurus surinamensis (autor původní fotografie Jacob Scott, @ Flickr, použito se svolením autora)

\section{Velikost těla}

Obecně v mnoha článcích zabývajících se danou tématikou vychází, že nejdůležitějším faktorem je velikost a tvar těla zvířete. Tyto se objevují průkazně a s mnohem větším efektem, než napřs. barevnost nebo vzorování. Tělesná velikost přitom přímo souvisí s tvarem, který se s větší velikostí zviŕrete alometricky mění. Přesto, že respondentům ukazujeme zvírata na obrázcích, kde jsou vůči sobě velikostně ve stejném poměru, právě díky alometrii si lidé (především kvůli různému poměru hlavy a očí k poměru zbytku těla) dovedou domyslet skutečnou velikost zvířete, včetně jeho stárí 
(v rozlišení mládě/dospělec; Pittenger, 1990). Tuto proměnnou tedy nelze nikdy plně odfiltrovat a v podobě tvaru těla se vždy bude v podobných testovaných souborech vyskytovat. Např. u savců je větší tělesná velikost hodnocena kladně (Frynta et al., 2009). Velcí savci jsou preferovaní a krásní a mnohdy tvoří také tzv. „charismatickou megafaunu“, což je pojem označující zvířata, jež mají vysoký potenciál pro zaujetí široké veřejnosti, a tudíž pro využití jakožto „vlajkových druhü“ v ochraně životního prostředí. Jsou jimi např. panda velká, velké kočkovité šelmy, sloni, nosorožci a velcí primáti (Leader-Williams \& Dublin, 2000; Poláková, 2016). Velcí savci jsou populární v zoologických zahradách (Ward, Mosberger, Kistler \& Fischer, 1998), ve kterých se také častěji vyskytují (Frynta et al., 2013). Ale i pokud je člověk hodnotí čistě podle vzhledu z obrázků, je ochoten více chránit velké savce než malé (Poláková, 2016). Lze si přitom odvodit, že i zde se velikost odráží v kráse, protože tito respondenti zároveň jeví vyšší ochotu chránit druhy hodnocené jako krásné než ty, jež vzbuzují odpor.

Oproti tomu jiným druhům zvířat může tělesná velikost naopak na kráse ubírat. To se projevuje např. na hadech: při hodnocení živých korálovek respondenti preferují drobnější, štíhlá zvířata (Landová et al., 2012). V př́ípadě hroznýšsvitých hadů a krajt se podobný efekt projevuje u dětí, které preferují štíhlejší a menší hady než dospělí respondenti (Ptáčková et al., 2017). Pokud vybereme jednoho zástupce $\mathrm{z}$ každé podčeledi, nemá naopak tělesná velikost na hodnocení vliv, a to ani u hadů, ani u ostatních plazů. Vliv velikosti se neprojevuje ani u želv, protože celkem pozitivně je vnímána celá skupina želv a želvy jako skupina jsou preferované oproti jiným plazům, at’ už jsou velké, nebo malé (Janovcová, 2015).

Podobně jako u hadů, i u ptáků má tělesná velikost na hodnocení krásy vliv, který je závislý na tom, jakou skupinu zrovna hodnotíme. U papoušků (Frynta et al., 2010) a puštíkovitých sov (Landová et al., 2014) platí, že větší druhy jsou hodnocené jako krásnější. U některých jiných skupin tělesná velikost roli nehraje, pravděpodobně proto, že daná skupina obsahuje př́liš málo variability ve velikosti, než aby na ni při hodnocení krásy mohl být brát zřetel. Ze studovaných skupin to lze pozorovat u volavek, tukanů, vousáků a zoborožců (Landová et al., 2014). Naopak vezmeme-li dva zástupce $\mathrm{z}$ každé čeledi (v dané studii byly zahrnuté jen nepěvčí čeledi, doplněné o pět čeledí pěvců), lidem jako krásnější přijdou ptáci, kteří jsou menší (Lišková \& Frynta, 2013). Důvodů může být několik. Je známo, že lidé preferují infantilní rysy (tzv. Lorenzovo dětské schema, Lorenz, 1942), tj. především velké oči a velkou hlavu v poměru ke zbytku těla, což jsou přesně rysy, které mají menší živočichové, včetně malých ptáků (viz Obr. 4). Na druhou stranu by zde mohla hrát roli i představa určitého prototypu ,ptáka“, protože vedle menší tělesné velikosti se lidem líbili i ptáci s krátkým krkem a dlouhým ocáskem, což odpovídá většině pěvců, a pěvců je více než polovina všech existujících druhů ptáků (Landová et al., 2014). 
a)

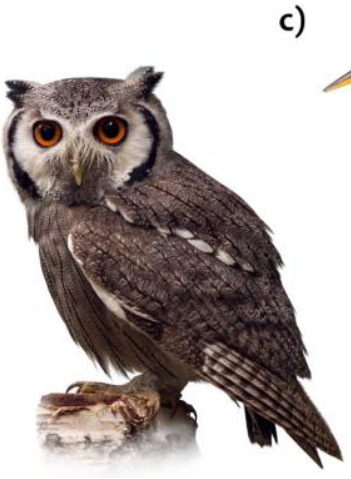

c)

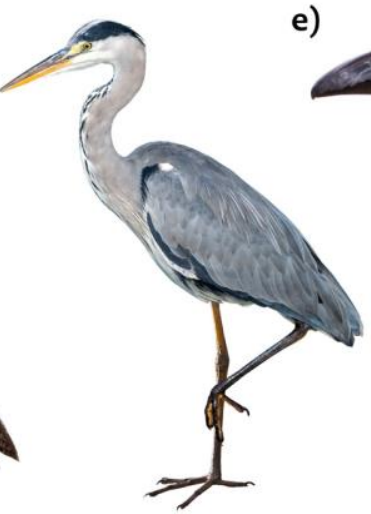

e)

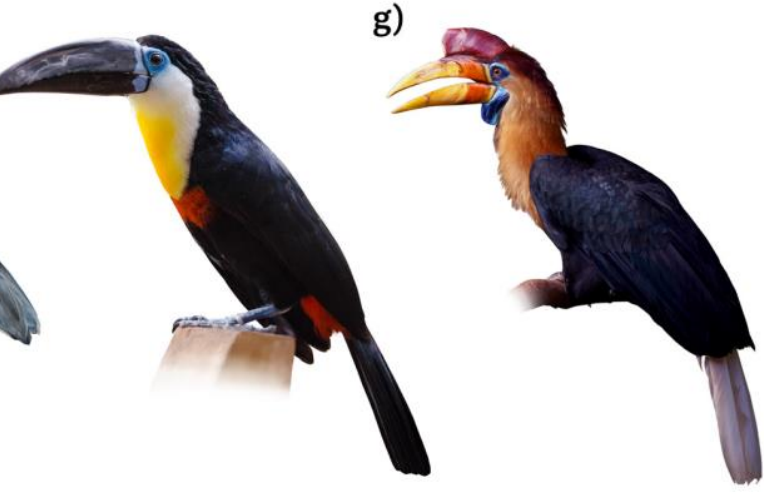

b)

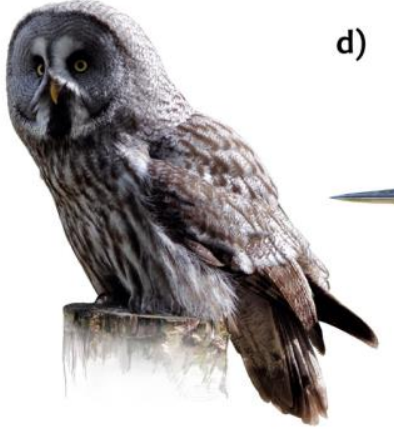

d)

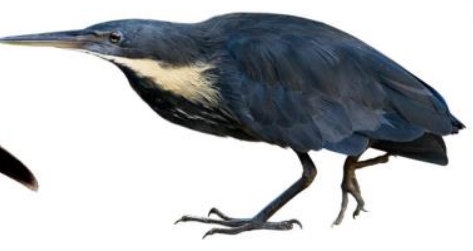

f)

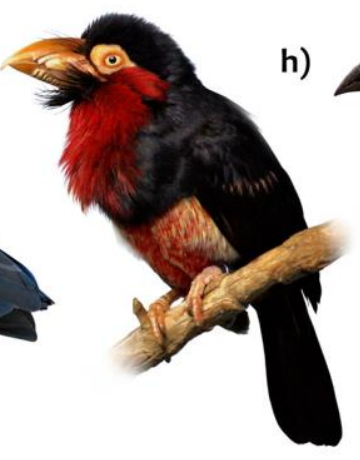

h)

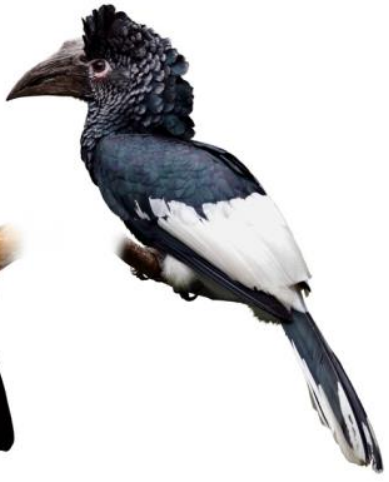

Obr. 4: Ukázka některých druhů ptáků, kteří byli v rámci své čeledi hodnocení jako nejkrásnější (nahoře) a nejméně krásní (,nejošklivější“, dole; Landová, Lišková, \& Frynta, 2014). Puštíkovití (Strigidae): a) výreček bělolící (Otus leucotis; autor fotografie Jason Thompson @ Flickr, CC BY 2.0 ), b) puštík vousatý (Strix nebulosa); volavkovití (Ardeidae): c) volavka popelavá (Ardea cinerea), d) bukáček černý (Ixobrychus flavicollis; autor fotografie Greg Miles@ Flickr, CC BY 2.0); tukanovití (Ramphastidae): e) tukan bělolící (Ramphastos vitellinus), f) vousák senegalský (Lybius dubius; autor fotografie Postdlf @ Wikimedia Commons, CC BY-SA 3.0); zoborožcovití (Bucerotidae): g) zoborožec př́lbový (Rhyticeros cassidix; autor fotografie Mashku @ Flickr, CC BY-NC-SA 2.0), h) zoborožec černobílý (Bycanistes subcylindricus; autor fotografie Bernard DUPONT @ Flickr, CC BY-SA 2.0).

\section{Tvar zvírete}

Jak již bylo řečeno, s velikostí zvířete úzce souvisí jeho tvar, který má také velmi významný vliv na to, zda bude lidskými respondenty zvíre rozpoznáno jako krásné. V práci Frynty a kol. (2009) byli jako nejoblíbenější savci z různých souborů hodnocení pišt’ucha horská (Ochotona alpina, Ochotonidae), komba rondská (Galago rondoensis, Galagidae) a panda červená (Ailurus fulgens, Ailuridae). Ačkoliv podrobnější analýza konkrétních faktorů ovlivňujících hodnocení respondentů nebyla dělána, lze pozorovat, že oblíbené jsou druhy vykazující dětské schema, tj. savci s velkýma očima, vysokým čelem a velkou hlavou. Oblíbené jsou druhy hodně chlupaté a zavalité připomínající plyšové medvídky a výsledky z práce Frynty a kol. (2013) to potvrzují, nebot' i zde byly jako nejoblíbenější čeledi savců hodnocené panda červená, kočkovité šelmy a koaly.

U jiných skupin zviŕat již byly dělány podrobnější analýzy konkrétních morfologických faktorů, které ovlivňují hodnocení krásy. U plazů např́íklad člověk rozlišuje dva morfotypy - typ ,ještěrka“ (ještěrky, želvy, krokodýli) a typ „had“ (hadi a beznozí ještěři). V každé z obou skupin jsou přitom 
druhy jak oblíbené, tak neoblíbené, nejvíce ke kráse přispívá délka hlavy, šířka krku, velikost očí a celková délka těla. U ještěrů pak má vliv přítomnost končetin (ještěři s končetinami jsou hodnocení jako krásnější), u hadů má vliv celkový tvar těla (Janovcová, 2015). Zajímavé je, že v daném prŕípadě nezáleží příliš na kontextu, ve kterém lidé plazy hodnotí - například u hadů vyšly výsledky stejné, at' už byli hodnocení v rámci celkového setu plazů, nebo pouze $\mathrm{v}$ samostatné sadě. Podobného rozdělení jako u plazů jsou respondenti schopní i při porovnávání krásy obojživelníků, kde se skupiny jasně dělí na nejoblíbenější žáby, nejméně krásné červory a na ocasaté obojživelníky, kde najdeme druhy krásnější i méně krásné. V rámci žab byla dělána i analýza konkrétních vlastností, které ovlivňují hodnocení krásy. Ukazuje se, že lidem se nejvíce líbí žáby se štíhlejším tělem, dlouhými končetinami a velkýma očima (Peléšková, 2016).

\section{Barvy}

V porovnání s tělesnou velikostí a tvarem hrají barvy v hodnocení krásy zvířat mnohem menší roli, a to i u druhů, jež jsou výrazně pestrobarevné (Lišková et al., 2015a). Barvy jsou důležitější achromatické, tj. černá, bílá a šedá, a často také hraje roli celkový světelný kontrast a kontrastní vzorování. Ze savců se např́klad často vyskytují jako oblíbené druhy, které jsou černobílé: zebry (Equus grevyi a E. zebra) a panda (Ailuropoda melanoleuca; Frynta et al. 2013), nebo vari černobílý (Varecia variegata), lemur kata (Lemur catta) a gibon tmavoruký (Hylobates agilis; Lišková, Landová \& Frynta, 2014). Velmi oblíbené je také vzorování kočkovitých šelem, přičemž jde ve skutečnosti spíše o větší kontrastní plochy než komplexní texturu. V práci Polákové (2016) byl vzor v analýze zahrnutý dvěma zpo̊soby, jednak jako kategorická proměnná $(0,1,2$ podle míry typického vzorování, jako má např. tygr) a jednak jako míra kontrastu mezi jednotlivými pixely na obrázku (měřeno jako světelnost obrázku po aplikaci filtru zvýrazňujícího hrany, spočítaného pomocí Sobelova operátoru, Sobel, 1978; v programu Barvocuc, Rádlová et al., 2016). První ze jmenovaných proměnných byla jedním z faktorů, jenž predikoval krásu savců nejvíce, zatímco druhá proměnná neměla na hodnocení respondentů žádný vliv. Tento typ vzorování se v daném setu projevoval hlavně jako drobná textura tzv. zbarvení aguti nebo jako bodliny ježury, ježka a osináka. Podobné výsledky lze pozorovat u hodnocení primátů, kde také aguti zbarvení nemělo žádný vliv na krásu a druhy takto zbarvené byly hodnoceny spíše jako méně oblíbené - např. kočkodan bělonosý (Cercopithecus nictitans) nebo kosman zakrslý (Cebuella pygmaea; Lišková, Landová \& Frynta, 2015b).

I u ptáků a plazů je černobílý kontrast a vzorování jedním z nejdůležitějších faktorů, podle kterého respondenti určují krásu hodnocených druhů. U ptáků je to názorně možné pozorovat na skupině pěvců z čeledi pitovití (Pittidae), kteří jsou si tvarově velmi podobní, ale liší se pestrými barvami i mírou vzorování v podobě malých vlnek. Zde respondenti měli za úkol seřadit podle krásy jednak barevný set obrázků a jednak achromatický set (oba sety byly hodnoceny různými respondenty). Ukázalo se, že lidé hodnotí krásu těchto pěvců převážně na základě jejich achromatického kontrastu a vzorování a význam barev že se sice projevuje, ale v mnohem menší míre (Lišková et al., 2015a). Vzorování se lidem líbí i u hadů. Dospělí respondenti i děti předškolního věku se shodují na tom, že nejkrásnější jsou vzorovaní hroznýši a krajty (Ptáčková et al., 2016), a podobně i výrazné vzorování černé barvy $\mathrm{v}$ kombinaci s červenou, které tvoří aposematické zbarvení mnoha korálovek, je vnímané jako krásné (Marešová et al., 2009b, Landová et al., 2012). Vzorování korálovek je navíc oblíbené i v př́ípadě, že se nachází na zjednodušených stimulech ve formě proužků, kruhů nebo zjednodušených ilustrací hadů, uniformně zatočených podobně jako hadi skuteční (Průšová, 2013).

Role chromatických barev v hodnocení krásy zvírat je oproti achromatickým faktorům mizivá. Je to zvláštní, nebot' vliv barev na člověka je velmi dobře studován a znám: barvy vyvolávají v člověku emoce (Gao et al., 2007), napomáhají k lepšímu rozeznávání objektů (Liebe, Fischer, Logothetis \& Rainer, 2009; Yip \& Sinha, 2002), hrají roli v selektivní pozornosti (Buechner, Maier, Lichtenfeld \& 
Schwarz, 2014) a mají i vliv na pozornost (Ioan et al., 2007) a vzrušení (Elliot \& Maier, 2007; Wilson, 1966). Přesto se př́liš neuplatňují v kráse zvířat, a to ani u druhů, které jsou výrazně zbarvené (Lišková \& Frynta, 2013). Výjimku tvoří modrá barva, která je preferovaná velmi často u všech možných skupin zvírat. Modrá má vliv na krásu ptáků, a to i v rámci jednotlivých skupin, pokud se u nich modrá barva vyskytuje: ze studovaných skupin se kladný efekt projevil u papoušků (Frynta et al., 2010), pit (Lišková et al., 2015a), tukanů a zoborožců (Landová et al., 2014) a v práci Frynty a kol. (2010) sice nebyl efekt barev analyzován, nicméně jako nejkrásnější ptáci se umístili ti modře zbarvení, např. mezi pěvci to byli jmenovitě motýlek angolský (Uraeginthus angolensis, Estrildinae), sýkora modřinka (Parus caeruleus, Parinae) a lejsek modrobílý (Cyanoptila cyanomelana, Muscicapini). Modří plazi bývají také často hodnocení jako nejkrásnější. Protože modré druhy jsou vzácné, nebývá možné efekt modré barvy analyzovat statisticky, ale modré nebo i jen mírně namodralé druhy jsou velmi oblíbené: např. korálovka šedá (Lampropeltis alterna), která měla jako jediná modrý nádech (Landová et al. 2012), nebo sytě tyrkysový leguán Dickersonův (Crotaphytus dickersonae; Janovcová, 2015) byli hodnocení v daných setech jako ti nejkrásnější. Efekt modré barvy vyšel průkazně u australských hadů (Průšová, Janovcová, Peléšková, Landová \& Frynta, 2017) a v sadě hroznýšů a krajt se tento efekt projevil průkazný i přesto, že někteří vyobrazení hadi nebyli přímo modř́, ale měli na sobě mírný modrý odlesk světla na šupinách (Ptáčková et al., 2016). Podobně se projevil i efekt čistě jen namodralého odlesku na fotografiích při hodnocení krásy obličejů primátů (Lišková et al., 2015b). Ve všech zmiňovaných prrípadech působila modrá barva pozitivně na vnímání krásy zvírat. Modrá barva navíc byla preferovaná i při hodnocení krásy květin (Hůla \& Flegr, 2016).

Další barvy, které se ve větší či menší míře uplatňují při hodnocení krásy zviřat, jsou zelená a žlutá. Žlutá vychází jako krásná u ptáků (Lišková \& Frynta, 2013) a skupin papoušků (Frynta et al., 2010) a zoborožců (Landová et al., 2014), zelená u pitovitých pěvců (Lišková et al., 2015a) a pozitivně působí také u některých ještěrů (Janovcová, 2015) a hadů (Ptáčková et al., 2016). Zelená barva však může mít i negativní efekt: v případě papoušků, u nichž je většina z 367 studovaných druhů zelená, tato barva na hodnocení krásy působila negativně (Frynta et al., 2010), a podobně působila i $\mathrm{v}$ príípadě savců, kde byla prítomna pouze jako odlesk trávy, který se v sadě vyskytoval kvůli charakteru použitých stimulů (Poláková, 2016).

Ze všech základních barev je nejvíce ambivalentní červená. Člověk může na červenou barvu podle kontextu reagovat jak pozitivně, tak negativně (Meier, D’agostino, Elliot, Maier \& Wilkowski, 2012). Kupř́kladu v pohlavním kontextu červená barva způsobuje, že se dotyčný stává v pohledu hodnotitele atraktivnějším (viz např. Elliot \& Niesta, 2008; Lin, 2014; Roberts, Owen \& Havlíček, 2010), a tento efekt se zdá být univerzální (Elliot, Tracy, Pazda \& Beall, 2013). Na druhou stranu může ale červená barva signalizovat nebezpečí a hrozbu a např. v kontextu soutěže se člověk může snažit této barvě spíše vyhýbat (Meier et al., 2012). Buechner a kol. (2014) ukázali, že červená barva zvyšuje pozornost vůči relevantním stimulům, resp. že signalizuje, že daný stimulus je důležitý a zasluhuje naši pozornost. V tomto kontextu nabízejí výsledky studie krásy zvířat zajímavou interpretaci. Ukázalo se totiž, že červená barva nehraje téměř nikdy roli v hodnocení krásy ptáků (Frynta et al., 2010; Lišková \& Frynta, 2013; Lišková et al., 2015a). Výjimku tvoří tukani, na nichž červená barva působí na hodnocení krásy negativně (Landová et al., 2014). Také načervenalí savci jsou hodnocení celkově spíše negativně (Poláková, 2016). Pozitivně však červená barva přispívá k hodnocení krásy u hadů (Landová et al., 2012; Marešová et al., 2009b; Průšová, 2013) a také u obojživelníků (Peléšková, 2016), což jsou zvířata prioritizovaná z hlediska přežití (hadi i žáby, které také bývají často jedovaté, mohou člověka př́mo ohrožovat na životě). Zároveň u nich aposematické červené zbarvení často signalizuje právě jedovatost a nebezpečnost (Toledo \& Haddad, 2009). Je tedy možné, že se lidem červená barva líbí proto, že upoutala jejich pozornost, 
a radost $\mathrm{z}$ toho, že člověk spatřil nebezpečné zvíře včas, se následně promítá i do „estetického prožitku“ při hodnocení krásy zvířete (Lišková et al., 2015a). Na druhou stranu se červená barva na studovaných korálovcích a korálovkách téměř vždy vyskytuje vedle kontrastních černých nebo černobílých pruhů, a je tedy možné, že ve skutečnosti efekt červené barvy vychází jen díky kontrastnímu vzorování. Na rozlišení těchto dvou hypotéz bude zapotřebí dalších studií.

\section{Mezikulturní shoda v pohledu na zvířata}

Jednou z hypotéz evoluční psychologie je, že si naši předkové vyvinuli adaptivní smysl vnímat jakousi ,atraktivitu zvířat" a preference určitých druhů dříve, než se člověk geograficky rozš́ŕíil a kulturně rozčlenil (Barkow, Cosmides \& Tooby, 1992). Proto na základě této hypotézy Frynta a kolektiv prováděli experimenty, které by ukázaly, zda existuje mezikulturní shoda v estetickém vnímání zvířat, a to pomocí předkládání obrázků druhů, které představují pro člověka evolučně důležité stimuly. Nejprve porovnávali estetické preference Evropanů (českých studentů) s vesničany z Papuy Nové Guiney a nechali je dle subjektivně zhodnocené krásy seřadit obrázky hroznýšovitých hadů (Marešová, Krása \& Frynta, 2009a). Papuánci pochází oproti Evropanům $\mathrm{z}$ velmi odlišného kulturního prostředí, a navíc žijí v těsném kontaktu s divokými zvířaty a především hady. V zoogeografické oblasti Austrálie (kam patř́ i Papua Nová Guinea) se vyskytuje mnoho silně jedovatých druhů hadů z čeledi korálovcovití (Elapidae; O'Shea, Warrell \& Lalloo, 1996). Rozumné by tedy bylo předpokládat, že se budou estetické preference hadů mezi Čechy a Papuánci lišit. Překvapivě však preference těchto dvou odlišných kultur silně korelovaly, s tím, že drobný rozdíl se projevil pouze v hodnocení šesti druhů $\mathrm{z}$ celkových dvaatřiceti (Marešová et al., 2009a). Rozdíly navíc nešlo vysvětlit osobní zkušeností ani významem daného druhu v lokální kultuře, nebot' čtyři testované druhy, které se běžně vyskytují v Nové Guinei, neměly na etnické odlišnosti v hodnocení vliv. V dalším kroku rozšíŕili Frynta a kolektiv (2011) studii o data získaná z pěti opět velmi kulturně odlišných částí světa: získali hodnocení lidských preferencí hroznýšovitých hadů z Bolívie (Jižní Amerika), Filipín (jihovýchodní Asie), Dillí a Rádžasthánu v Indii (jižní Asie), Maroka (severní Afrika) a Malawi (sub-saharská Afrika). Shoda mezi těmito kulturami a Papuánci byla ještě užší než mezi Papuánci a Čechy, a to i přesto, že se zkušenosti s prezentovanými druhy $\mathrm{v}$ každé ze studovaných lokalit liší: je rozdílná místní fauna jednotlivých druhů, lidé se s nimi setkávají různou měrou a také se velmi liší postoj místních lidí k médiím, jako je třeba televize.

V další srovnávací studii předkládali Landová a kolektiv (2018) obrázky 36 druhů hadů z oblasti Evropy, severní Afriky a Středního východu respondentům z Ázerbájdžánu (jihozápadní Asie), jejichž hodnocení pak srovnávali opět s českými studenty. Tentokrát měli respondenti za úkol řadit obrázky dvakrát, jednou podle krásy a podruhé podle strachu. Ukázalo se, že ani v jedné škále se hodnocení těchto dvou kultur výrazně neliší, a navíc že znaky, podle kterých respondenti určovali, zda jsou hadi krásní, či zda vypadají nebezpečně, se též mezi oběma skupinami shodovaly. Konkrétně se Češi a Ázerbájdžánci bojí hadů se širokou hlavou a ocasem, velkýma očima a tmavší barvou, naopak druhy s dlouhým tělem a narůžovělou barvou hodnotí jako neškodné. Za krásné považují obě skupiny hady s komplexním vzorováním a nelíbí se jim růžové druhy s bílým odleskem, který pravděpodobně evokuje ,slizkost“".

Výše zmiňovaná shoda mezi různými národy neplatí čistě pro hodnocení hadů, ale též pro zvířata, jakými jsou ještěři, želvy, ptáci a savci, což bylo testováno v Evropě a východní Indonésii (vlastní nepublikované výsledky). Dané výsledky lze vysvětlit bud’to tím, že jsou lidské preference určeny primordiálními smyslovými mechanismy sdílenými všemi lidmi (a pravděpodobně i př́buznými primáty; shoda $\mathrm{v}$ estetických preferencích totiž do jisté míry platí i na některé neživé předměty 
a umělecká díla, viz např. Child \& Siroto, 1965; Ford, Prothro \& Child, 1966; nebo Iwao, Child \& García, 1969), nebo tím, že se neurální mechanismy zaměřené na zpracovávání živých objektů (zviŕrat) vyvinuly v odpovědi na selekční tlak, který ovlivňoval předky člověka v minulosti. Obě hypotézy se navíc vzájemně nevylučují. Tak či onak, sdílený pohled na zvířecí krásu mezi odlišnými kulturami představuje nesmírně důležitý fenomén. Mohl by být také př́kladem jedné z tzv. lidských univerzálií, tedy vlastností, jež jsou sdíleny mezi všemi populacemi a kulturami na celém světě (Brown, 2004).

\section{Závěr}

Zvířata vždy představovala pro člověka důležitou součást jeho života, a to nejen $\mathrm{z}$ hlediska možného ohrožení či jako zdroj potravy, ale představují i významné objekty, které v něm mohou vyvolat pozitivní emoce. Pokud lidé hodnotí zviŕata z hlediska „viděné“ krásy, je pro ně důležitá zejména velikost, tvar těla zvířete a achromatické zbarvení. Na druhou stranu, barvy kupodivu, snad kromě modré, nemají již tak významný efekt. Důležité ovšem je, jakou konkrétní skupinu zviřat lidé hodnotí, od toho se odvíjí i to, které znaky budou ke kráse přispívat a které je budou činit spíše „ošklivými“. Pozitivní vztah lidí ke zvířatům se podle evolučních hypotéz formoval již v období vzniku moderního člověka, tedy před tím, než se rozšiřril po celém světě. Tuto myšlenku podporují i výsledky mnoha studií porovnávající vnímání krásy zvířat lidmi z různých částí světa. Ačkoliv lidé žijí v různém kulturním prostředí, mají odlišné zkušenosti s místní faunou a různý vztah ke zviŕatům jako takovým, $\mathrm{v}$ hodnocení, která zvířata jsou krásná a jaké znaky to ovlivňují, se významně shodují. Výzkum pozitivního vztahu lidí ke zviřatům a zjištění, co ho ovlivňuje, je zároveň nesmírně důležitý pro ochranu ohrožených druhů. Ukazuje se, že krásná, charismatická a preferovaná zvířata jsou častěji předmětem záchranných programů a celkově je jim věnováno více pozornosti (Metrick \& Weitzman, 1996; Seddon, Soorae \& Launay, 2005; Small, 2011). Ovšem nalezneme velké množství druhů, které jsou kriticky ohrožené, ale z estetického hlediska nejsou pro lidi atraktivní. Proto je důležité vědět, zda konkrétní druh dokáže zaujmout pozornost lidí sám o sobě (a tím přimět širokou veřejnost $k$ podpoře jeho záchranného programu) nebo je nutné pro jeho záchranu zvolit jinou strategii. Pro příklad nemusíme chodit daleko. Například velemlok čínský (Andrias davidianus) patří mezi kriticky ohrožené obojživelníky, nicméně při hodnocení respondenty vychází jako spíše „ošklivý“ druh (Peléšková, 2016). Zoologická zahrada v Praze však pro tento druh vybudovala moderní pavilon s interaktivními prvky, které přitahují pozornost návštěvníků. Tedy ač je velemlok z hlediska krásy nepreferovaný, vhodně cílená „reklama“ učinila z tohoto druhu atraktivní zvíře a doufejme, že pomůže i k jeho budoucí záchraně ve volné př́rodě.

\section{Poděkování}

Tato studie je výsledkem badatelské činnosti podporované projektem číslo LO1611 za finanční podpory MŠMT v rámci programu NPU I.

\section{Literatura}

Almeida, A., Vasconcelos, C., \& Strecht-Ribeiro, O. (2014). Attitudes toward animals: A study of Portuguese children. Anthrozoös, 27(2), 173-190.

Barkow, J. H., Cosmides, L. E., \& Tooby, J. E. (1992). The adapted mind: Evolutionary psychology and the generation of culture. Oxford University Press.

Berlin, B. (1992). Ethnobiological classification: Principles of categorization of plants and animals in traditional societies. Princeton: Princeton University Press. 
Berlin, B. (1978). Ethnobiological classification. In E. Rosch, B. B. Lloyd (Eds.), Cognition and Categorization. Hillsdale, NJ: Lawrence Erlbaum Associates, Inc.

Brown, D. E. (2004). Human universals, human nature \& human culture. Daedalus, 133(4), 47-54.

Buechner, V. L., Maier, M. A., Lichtenfeld, S., \& Schwarz, S. (2014). Red-take a closer look. PLoS One, 9(9), e108111.

Burgdorf, J., \& Panksepp, J. (2006). The neurobiology of positive emotions. Neuroscience \& Biobehavioral Reviews, 30(2), 173-187.

Burgin, C. J., Colella, J. P., Kahn, P. L., \& Upham, N. S. 2018. How many species of mammals are there? Journal of Mammalogy 99, 1-11.

Child, I. L., \& Siroto, L. (1965). Bakwele and American esthetic evaluations compared. Ethnology, 4(4), 349-360.

Ekman, P., \& Cordaro, D. (2011). What is meant by calling emotions basic. Emotion Review, 3(4), 364-370.

Elliot, A. J., \& Maier, M. A. (2007). Color and psychological functioning. Current Directions in Psychological Science, 16(5), 250-254.

Elliot, A. J., \& Niesta, D. (2008). Romantic red: red enhances men's attraction to women. Journal of Personality and Social Psychology, 95(5), 1150.

Elliot, A. J., Tracy, J. L., Pazda, A. D., \& Beall, A. T. (2013). Red enhances women's attractiveness to men: First evidence suggesting universality. Journal of Experimental Social Psychology, 49(1), 165-168.

Ford, C. S., Prothro, E. T., \& Child, I. L. (1966). Some transcultural comparisons of esthetic judgment. The Journal of Social Psychology, 68(1), 19-26.

Frynta, D., Landová, E., \& Lišková, S. (2014): Animal Beauty, Cross-Cultural Perceptions. In A. C Michalos (Ed.), Encyclopedia of quality of life and well-being research. Dordrecht, The Netherlands: Springer.

Frynta, D., Lišková, S., Bültmann, S., \& Burda, H. (2010). Being attractive brings advantages: the case of parrot species in captivity. PloS one, 5(9), e12568.

Frynta, D., Marešová, J., Landová, E., Lišková, S., Šimková, O., Tichá, I., . . Fuchs, R. (2009). Are animals in zoos rather conspicuous than endangered? In A. M. Columbus and L. Kuznetsov (Eds.), Endangered species: New research (pp. 299-341). New York: Nova Science Publishers.

Frynta, D., Marešová, J., Řeháková-Petrů, M., Šklíba, J., Šumbera, R., \& Krása, A. (2011). Cross-cultural agreement in perception of animal beauty: Boid snakes viewed by people from five continents. Human Ecology, 39(6), 829-834.

Frynta, D., Šimková, O., Lišková, S., \& Landová, E. (2013). Mammalian collection on Noah's Ark: the effects of beauty, brain and body size. PLoS One, 8(5), e63110.

Gao, X. P., Xin, J. H., Sato, T., Hansuebsai, A., Scalzo, M., Kajiwara, K., ... \& Billger, M. (2007). Analysis of cross-cultural color emotion. Color Research \& Application, 32(3), 223-229.

Gunnthorsdottir, A. (2001). Physical attractiveness of an animal species as a decision factor for its preservation. Anthrozoos: A Multidisciplinary Journal of The Interactions of People \& Animals, 14, 204215.

Hůla, M., \& Flegr, J. (2016). What flowers do we like? The influence of shape and color on the rating of flower beauty. PeerJ, 4, e2106. https://doi.org/10.7717/peerj.2106

Ioan, S., Sandulache, M., Avramescu, S., Ilie, A., Neacsu, A., Zagrean, L., \& Moldovan, M. (2007). Red is a distractor for men in competition. Evolution and Human Behavior, 28(4), 285-293.

IUCN (2017). The IUCN Red List of Threatened Species. Version 2017-3. http://www.iucnredlist.org 
Iwao, S., Child, I. L., \& García, M. (1969). Further evidence of agreement between Japanese and American esthetic evaluations. The Journal of Social Psychology, 78(1), 11-15.

Jacobsen, T., Buchta, K., Köhler, M., \& Schröger, E. (2004). The primacy of beauty in judging the aesthetics of objects. Psychological Reports, 94, 1253-1260.

Janovcová, M. (2015). Faktory ovlivňujici velikost zoo populaci u ještěrů, hadů, želv a krokodýlů: efekt stupně ohrožení, velikosti a atraktivity pro člověka. Nepublikovaná diplomová práce. Univerzita Karlova, Př́rodovědecká fakulta, Katedra zoologie, Praha.

Kühn, S., \& Gallinat, J. (2012). The neural correlates of subjective pleasantness. Neuroimage, 61(1), 289294.

Landová, E., Bakhshaliyeva, N., Janovcová, M., Peléšková, Š., Suleymanova, M., Polák, J., ... \& Frynta, D. (2018). Association between fear and beauty evaluation of snakes: Cross-cultural findings. Frontiers in Psychology, 9, 333.

Landová, E., Lišková, S., \& Frynta, D. (2014). Je krása zviŕat vstupenkou na archu Noemovu? In O. Dadejík, F. Jaroš, M. Kaplický (Eds.), Krása a zvíre. Studie o vztahu estetických a etických hodnot zvírat. 33-102. Praha: Dokořán.

Landová, E., Marešová, J., Šimková, O., Cikánová, V., \& Frynta, D. (2012). Human responses to live snakes and their photographs: evaluation of beauty and fear of the king snakes. Journal of Environmental Psychology, 32(1), 69-77.

Leader-Williams, N., \& Dublin, H. T. (2000). Charismatic megafauna as 'flagship species'. In A. Entwistle, $\&$ N. Dunstone Eds.), Priorities for the conservation of mammalian diversity. Has the panda had its day? 53-81. Cambridge, UK: Cambridge University Press.

Liebe, S., Fischer, E., Logothetis, N. K., \& Rainer, G. (2009). Color and shape interactions in the recognition of natural scenes by human and monkey observers. Journal of Vision, 9(5), 14-14.

Lišková, S. (2013). Analysis of factors affecting human preferences and thus effort given to the conservation of animal species. Unpublished doctoral dissertation. Prague: Charles University. https://is.cuni.cz/webapps/zzp/detail/83343/?lang=en

Lišková, S., \& Frynta, D. (2013). What determines bird beauty in human eyes? Anthrozoös, 26(1), 27-41.

Lišková, S., Landová, E., \& Frynta, D. (2014). The beauty of primates: do we perceive our closest relatives as attractive? Poster session presented at the European Conference on Behavioural Biology, Prague, Czech Republic, July 17-20, 2014.

Lišková, S., Landová, E., \& Frynta, D. (2015a). Human preferences for colorful birds: Vivid colors or pattern? Evolutionary Psychology, 13(2). https://doi.org/10.1177/147470491501300203.

Lišková, S., Landová, E., \& Frynta, D. (2015b). Podle sebe soudím tebe: krása primátů očima člověka. Př́spěvek na 42. etologické konferenci, České Budějovice, 4. - 7.11. 2015.

Lin, H. (2014). Red-colored products enhance the attractiveness of women. Displays, 35(4), 202-205.

Liu, X., Hairston, J., Schrier, M., \& Fan, J. (2011). Common and distinct networks underlying reward valence and processing stages: a meta-analysis of functional neuroimaging studies. Neuroscience \& Biobehavioral Reviews, 35(5), 1219-1236.

Lorenz, K. (1942). Die angeborenen Formen möglicher Erfahrung. Zeitschrift für Tierpsychologie. https://doi.org/10.1111/j.1439-0310.1943.tb00655.x

Marešová, J., Krása, A. \& Frynta, D. (2009a). We all appreciate the same animals: Cross-cultural comparison of human aesthetic preferences for snake species in Papua New Guinea and Europe. Ethology, 115 (4), 297 300 . 
Marešová, J., Landová, E., \& Frynta, D. (2009b). What makes some species of milk snakes more attractive to humans than others? Theory in Biosciences, 128(4), 227.

Matchett, G., \& Davey, G. C. (1991). A test of a disease-avoidance model of animal phobias. Behaviour Research and Therapy, 29(1), 91-94.

Meier, B. P., D'agostino, P. R., Elliot, A. J., Maier, M. A., \& Wilkowski, B. M. (2012). Color in context: Psychological context moderates the influence of red on approach-and avoidance-motivated behavior. PloS one, 7(7), e40333.

Metrick, A., \& Weitzman, M. L. (1996). Patterns of behavior in endangered species preservation. Land Economics, 1-16.

Myers, O. E., Saunders, C. D., \& Birjulin, A. A. (2004). Emotional dimensions of watching zoo animals: An experience sampling study building on insights from psychology. Curator: The Museum Journal, 47(3), 299-321.

O'Shea, M., Warrell, D. A., \& Lalloo, D. G. (1996). A guide to the snakes of Papua New Guinea (No. 147). Independent Publishing House.

Peléšková, Š. (2016). Pozitivní a negativni vztah ke zvíratům. Nepublikovaná diplomová práce. Univerzita Karlova, Př́rodovědecká fakulta, Katedra zoologie, Praha.

Pittenger, J. B. (1990). Body proportions as information for age and cuteness: Animals in illustrated children's books. Attention, Perception, \& Psychophysics, 48(2), 124-130.

Polák, J., Sedláčková, K., Nácar, D., Landová, E., \& Frynta, D. (2016). Fear the serpent: A psychometric study of snake phobia. Psychiatry Research, 242, 163-168.

Poláková, P. (2016). Vnimání krásy savců v ZOO Praha: vliv věku a vzdělání respondentů. Nepublikovaná diplomová práce. Univerzita Karlova, Př́rodovědecká fakulta, Katedra zoologie, Praha.

Pothos, E. M., \& Chater, N. (2002). A simplicity principle in unsupervised human categorization. Cognitive Science, 26(3), 303-343.

Pothos, E. M., \& Close, J. (2008). One or two dimensions in spontaneous classification: A simplicity approach. Cognition, 107(2), 581-602.

Průšová, L. (2013). Experimentalní výzkum specificity strachu z hadů u lidí: korálovcovitý vzor. Nepublikovaná diplomová práce. Univerzita Karlova, Př́rodovědecká fakulta, Katedra zoologie, Praha.

Průšová, L., Janovcová, M., Peléšková, Š., Landová, E., \& Frynta, D. (2017). Had jako evolučně relevantní stimul strachu. Sbornik abstraktů z konference „Zoo je věda“, Praha, 11. března 2017.

Ptáčková, J., Landová, E., Lišková, S., Kuběna, A., \& Frynta, D. (2017). Are the aesthetic preferences towards snake species already formed in pre-school aged children?. European Journal of Developmental Psychology, 14(1), 16-31.

Rádlová, S., Viktorin, P., \& Frynta, D. (2016). Barvocuc 2.0, Software for Color Image Analysis. Available for download at: http://www.nudz.cz/en/w_group/wg-on-emotions-and-phobias-triggered-by-animals/

Roberts, S. C., Owen, R. C., \& Havlíček, J. (2010). Distinguishing between perceiver and wearer effects in clothing color-associated attributions. Evolutionary Psychology, 8(3),

http://dx.doi.org/10.1177/147470491000800304.

Rodhouse, P. G., Griffiths, H. J., \& Xavier, J. C. (2014). Southern Ocean squid. In C. De Broyer P. Koubbi, H. J. Griffiths, B. Raymond, C. d' Udekem d'Acoz, et al. (Eds.). Biogeographic Atlas of the Southern Ocean. 284-289. Cambridge: Scientific Committee on Antarctic Research.

Seddon, P. J., Soorae, P. S., \& Launay, F. (2005). Taxonomic bias in reintroduction projects. Animal Conservation Forum, 8(1), 51-58.

Seligman, M. E. (1971). Phobias and preparedness. Behavior Therapy, 2(3), 307-320. 
Small, E. (2011). The new Noah's Ark: beautiful and useful species only. Part 1. Biodiversity conservation issues and priorities. Biodiversity, 12(4), 232-247.

Sobel, I. (1978). Neighborhood coding of binary images for fast contour following and general binary array processing. Computer Graphics and Image Processing, 8, 127-135.

Thornhill, R. (2003). Darwinian aesthetics informs traditional aesthetics. In EvolutionaryAesthetics. 9-35. Berlin, Heidelberg: Springer.

Toledo, L. F., \& Haddad, C. F. (2009). Colors and some morphological traits as defensive mechanisms in anurans. International Journal of Zoology, Article ID 910892, 1-12.

Torkar, G., Kubiatko, M., \& Bajd, B. (2012). Assessing pre-service teachers (dis)liking of some animal species. Journal of Baltic Science Education, 11(4).

Ward, P. I., Mosberger, N., Kistler, C., \& Fischer, O. (1998). The relationship between popularity and body size in zoo animals. Conservation Biology, 12(6), 1408-1411.

Wilson, E. O. (1984). Biophilia. London: Harvard University Press.

Wilson, G. D. (1966). Arousal properties of red versus green. Perceptual and Motor Skills, 23, 947-949.

Woods, B. (2000). Beauty and the beast: Preferences for animals in Australia. Journal of Tourism Studies, $11(2), 25$.

Yasuoka, H. (2006). Long-term foraging expeditions (Molongo) among the Baka hunter-gatherers in the Northwestern Congo Basin, with special reference to the "wild yam question". Human Ecology, 34(2), 275296.

Yip, A. W., \& Sinha, P. (2002). Contribution of color to face recognition. Perception, 31(8), 995-1003.

\section{Údaje o autorech}

RNDr. Silvie Rádlová, Ph.D. (roz. Lišková) pracuje v Národním ústavu duševního zdraví (NUDZ) v Klecanech ve skupině zkoumající fobie vyvolané zviŕaty. Je absolventkou Přírodovědecké fakulty UK a v minulosti pracovala pro Zoologickou zahradu v Praze. Zabývá se vizuálním vnímáním zvířat lidmi a grafickými pracemi při přípravě testovacích stimulů.

Adresa: Národní ústav duševního zdraví, Topolová 748, 25067 Klecany

E-mail: silvie.radlova@nudz.cz

Mgr. Markéta Janovcová studuje obor Zoologie na Př́rodovědecké fakultě UK v Praze a pracuje na disertační práci týkající se emocí vyvolaných zvíraty u lidí. Současně pracuje v Národním ústavu duševního zdraví v Klecanech. V roce 2015 se stala spoluřešitelkou grantového projektu UK (č. 346315) a v roce 2018 spoluřešitelkou grantového projektu UK (č.1636218).

Adresa: Př́rodovědecká fakulta Univerzity Karlovy, Viničná 7, 12843 Praha 2

Národní ústav duševního zdraví, Topolová 748, 25067 Klecany

E-mail: Marketa.Janovcova@nudz.cz

Mgr. et Mgr. Jakub Polák, Ph.D. pracuje v Národním ústavu duševního zdraví (NUDZ) v Klecanech ve skupině zkoumající fobie vyvolané zvířaty. Je absolventem Př́rodovědecké fakulty UK a současně absolventem oboru Psychologie na Filozofické fakultě UK. V současnosti je spoluřešitelem projektu GAČR (č. 17-15991S).

Adresa: Národní ústav duševního zdraví, Topolová 748, 25067 Klecany

E-mail: Jakub.Polak@nudz.cz 
RNDr. Eva Landová, Ph.D. pracuje na katedře zoologie Př́rodovědecké fakulty UK v Praze a současně v Národním ústavu duševního zdraví v Klecanech ve skupině zkoumající fobie vyvolané zvírraty. V současnosti je hlavní řešitelkou projektu GAČR (č. 17-15991S), vedoucí grantových projektů UK č. 1310414 a 346315.

Adresa: Národní ústav duševního zdraví, Topolová 748, 25067 Klecany

E-mail: Eva.Landova@nudz.cz

doc. RNDr. Daniel Frynta, Ph.D. pracuje na katedře zoologie Př́rodovědecké fakulty UK v Praze a současně v Národním ústavu duševního zdraví v Klecanech, kde vede skupinu zkoumající fobie vyvolané zvířaty. V současnosti je spolořešitelem projektu GAČR (č. 17-15991S) a vedoucím grantového projektu UK č. 900217.

Adresa: Národní ústav duševního zdraví, Topolová 748, 25067 Klecany

E-mail: Daniel.Frynta@nudz.cz

Rádlová, S., Janovcová, M., Polák, J., Landová, Eva, \& Frynta, D. (2018). Emoce vyvolané zvíraty I: Krása a estetické preference. E-psychologie, 12(3), 35-50. https://doi.org./10.29364/epsy.324. 